\title{
Shiga toxin-producing Escherichia coli in beef retail markets from Argentina
}

\section{Victoria Brusa ${ }^{1}$, Virginia Aliverti ${ }^{1}$, Florencia Aliverti ${ }^{1}$, Emanuel E. Ortega ${ }^{1}$, Julian H. de la Torre ${ }^{1}$, Luciano H. Linares ${ }^{1}$, Marcelo E. Sanz ${ }^{2}$, Analía I. Etcheverría ${ }^{2}$, Nora L. Padola ${ }^{2}$, Lucía Galli', Pilar Peral García ${ }^{1}$, Julio Copes ${ }^{1}$ and Gerardo A. Leotta ${ }^{1 *}$}

Laboratorio de Microbiología de Alimentos, Instituto de Genética Veterinaria "Ing. Fernando N. Dulout," Facultad de Ciencias Veterinarias, Universidad Nacional de La Plata, CCT-La Plata, CONICET, Buenos Aires, Argentina

2 Inmunoquímica y Biotecnología, CIVETAN, CONICET-CICPBA, Facultad de Ciencias Veterinarias, Universidad Nacional del Centro de la Provincia de Buenos Aires, Buenos Aires, Argentina

\section{Edited by:}

Alfredo G. Torres, University of Texas Medical Branch, USA

Reviewed by:

Eric Cox, Ghent University, Belgium

Peter Feng, U.S. Food and Drug

Administration, USA

\section{*Correspondence:}

Gerardo A. Leotta, Laboratorio de

Microbiología de Alimentos,

Instituto de Genética Veterinaria

"Ing. Fernando N. Dulout," Facultad de Ciencias Veterinarias,

Universidad Nacional de La Plata, Calle 60 y 118 s/n, La Plata, Buenos

Aires, Bs As 1900, Argentina.

e-mail: gleotta@fcv.un/p.edu.ar
Shiga toxin-producing Escherichia coli (STEC) are foodborne pathogens that cause mild or serious diseases and can lead to people death. This study reports the prevalence and characteristics of STEC 0157 and non-O157 in commercial ground beef and environmental samples, including meat table, knife, meat mincing machine, and manipulator hands $(n=450)$ obtained from 90 retail markets over a nine-month period. The STEC isolates were serotyped and virulence genes as stx (Shiga toxin), rfb $\left.b_{0157}\right]$ (O157 lipopolysaccharide), $\mathrm{fli}_{\mathrm{H}}$ ( $\mathrm{H} 7$ flagellin), eae (intimin), ehxA (enterohemolysin) and saa (STEC autoagglutinating adhesin), were determined. STEC 0157 were identified in $23(25.5 \%)$ beef samples and $16(4.4 \%)$ environmental samples, while STEC non-O157 were present in $47(52.2 \%)$ and $182(50.5 \%)$, respectively. Among 54 strains isolated, 17 were STEC 0157:H7 and 37 were STEC non-0157. The prevalent genotype for O157 was stx $x_{2} /$ eae/ehxA/fli $\mathrm{CH}_{\mathrm{H}}(83.4 \%$ ), and for STEC non-O157 the most frequent ones were stx $x_{1} /$ st $x_{2} /$ saa/ehxA (29.7\%); stx 2 (29.7\%); and stx $x_{2} /$ saa/ehxA (27\%). None of the STEC non-0157 strains were eae-positive. Besides O157:H7, other 20 different serotypes were identified, being $\mathrm{O} 8: \mathrm{H} 19, \mathrm{O} 178: \mathrm{H} 19$, and $\mathrm{O} 174: \mathrm{H} 28$ the prevalent. Strains belonging to the same serotype could be isolated from different sources of the same retail market. Also, the same serotype could be detected in different stores. In conclusion, screening techniques are increasingly sensitive, but the isolation of STEC non-O157 is still a challenge. Moreover, with the results obtained from the present work, although more studies are needed, cross-contamination between meat and the environment could be suspected.

Keywords: STEC, raw ground beef, retail markets, environmental samples, Argentina

\section{INTRODUCTION}

Foodborne illnesses are defined as diseases, usually either infectious or toxic in nature, caused by agents that enter the body through the ingestion of food. Shiga toxin-producing Escherichia coli (STEC) are a group of food and water-borne pathogens associated with a wide spectrum of human diseases, ranging from mild diarrhea to hemorrhagic colitis (HC), thrombocytopenia, hemolytic uremic syndrome (HUS), and can also lead to people death (Karmali et al., 2010). Argentina has a high incidence of HUS: 17 cases per 100,000 children younger than 5 years, one of the highest in the world (Rivas et al., 2010). This rate is 10-fold higher than in other industrialized countries (Mead and Griffin, 1998). In Argentina, STEC is the primary etiological agent of HUS (Leotta et al., 2008), and E. coli $\mathrm{O} 157: \mathrm{H} 7$ is the predominant serotype isolated. However, other serotypes were associated with HUS (Guth et al., 2011).

Ruminants have been identified as the major reservoir of STEC (Karmali et al., 2010) and a variety of foods have been identified as vehicles of illnesses. However, approximately $52 \%$ of outbreaks have been associated with bovine products. Contamination of carcasses with STEC can occur when gut contents or fecal matter contact the meat surfaces, also crosscontamination between carcasses may occur during processing (Edwards and Fung, 2006). Studies of STEC prevalence in feces and carcasses of bovines from selected beef exporting abattoirs of Argentina showed that STEC non-O157 was present in 22.3\% and in $9.0 \%$ of the feces and bovine carcasses (Masana et al., 2011 ), and the prevalence of STEC O157 was $4.1 \%$ and $2.6 \%$, respectively (Masana et al., 2010). In other study $12.34 \%$ and $18.64 \%$ of STEC in carcasses, were detected at the slaughter and sanitary control cabin, respectively. These percentages increased at butcheries (24.52\%) from the same city. The $25 \%$ of retail beef cuts were STEC-positive with significant differences among the different cuts of meat (chuck: $12.12 \%$, rump roast: $12.12 \%$ and minced beef: $40.74 \%$ ) (Etcheverría et al., 2010). Comparatively, the prevalence of STEC non-O157 in the USA beef cattle feces has been shown to range from 19 to $30 \%$ 
(Barkocy-Gallagher et al., 2003; Renter et al., 2005) and the prevalence in hides was 56.3\% (Barkocy-Gallagher et al., 2003).

Some studies of STEC prevalence in minced beef samples were made in Argentina, in one of them, 3.8\% of O157:H7 was detected (Chinen et al., 2001) while Parma et al. (2000) found serotypes mainly non-O157. Studies in France, Australia, and the USA determined a STEC prevalence of approximately $16 \%$ in minced beef samples (Bohaychuk et al., 2006), while in Spain (Mora et al., 2007) the prevalence was $12 \%$.

Until present, there have not been systematic studies on local ground beef retail markets to assess the microbiological quality of meat, but also including verification of good hygiene practices, handlers' habits and traceability of the raw material. In Argentina, the microbiological quality of the meat sold at retail markets is based on the parameters specified at the Argentine Food Code. However, for STEC strains only O157:H7 serotype is mandatory, and the searching for potentially pathogenic bacteria for consumers on surfaces that contact with the meat is not established.

The aims of this study were the detection, isolation, and characterization of STEC strains in ground beef and environmental sponge samples, including meat table, knife, meat mincing machine, and manipulator hands, in ground beef retail markets, and to determine the pathogenic potential of the circulating strains. It also attempts to establish potential cross-contamination throw surfaces.

\section{MATERIALS AND METHODS SAMPLE COLLECTION}

From October 2010 to July 2011, 450 samples (90 raw ground beef and 360 environmental samples) were weekly collected from 90 retail stores in Berisso city, Buenos Aires province, Argentina. Sampling collection was randomly performed and covered all the geographic areas of the city. Environmental samples were obtained from meat contact surfaces such as meat tables, knives, meat mincing machines, and manipulator hands, following the protocol described below. From meat tables, three $400 \mathrm{~cm}^{2}$ areas were sampled with a sterile sponge soaked in buffered peptone water (Biokar, Zac de Ther, France). The entire surface of the knife blade and the intersection between the blade and the blade handle were sponged. The meat mincing machine was disassembled and the sample was taken from the meat container, the worm meat grinder, and the screw ring. Both hands (front, back, and nails) of the manipulator were sampled. All samples were ice refrigerated and sent to the laboratory to be analyzed immediately.

\section{CULTURE ENRICHMENT, PCR ASSAY, AND ISOLATION}

The samples were analyzed by duplicate. One replicate was processed according to US Department of Agriculture, Food Safety and Inspection Service (FSIS) methodology MLG 5.05 for E. coli O157:H7 (USDA-FSIS, 2010), and the other for STEC screening. Briefly, a $65 \mathrm{~g}$ portion of raw ground beef was placed aseptically in a plastic bag with $585 \mathrm{~mL}$ of modified tryptic soy broth (mTSB) with $20 \mathrm{mg} / \mathrm{L}$ of novobiocin and casaminoacids (Acumedia Manufacturers, USA). To the sponges $100 \mathrm{ml}$ of mTSB with $20 \mathrm{mg} / \mathrm{L}$ novobiocin plus casaminoacids were added. After homogenizing in a stomacher (Interscience, Saint Nom, France), each sample was incubated for 15-22 h at $42^{\circ} \mathrm{C}$. All the samples were processed by immunomagnetic separation (IMS) (Dynal Biotech, Oslo, Norway) according to the manufacturer's instructions, and plated onto CT-SMAC (Oxoid, Basingstoke, Inglaterra) and SD39 (Acumedia). Suspect colonies were screened for $s t x_{1}, s t x_{2}$, and $r f b_{\mathrm{O} 157}$ genes by multiplex PCR (Leotta et al., 2005). For STEC screening $25 \mathrm{~g}$ of raw ground beef and environmental samples were incubated at $41.5^{\circ} \mathrm{C}$ for 15-22 h in $225 \mathrm{~mL}$ modified E. coli broth (mEC) (Acumedia) and $90 \mathrm{~mL}$ of $\mathrm{mEC}$ (Acumedia), respectively. One milliliter of the broth culture was taken for DNA extraction, using triton $1 \%$ in TE $1 \times$, to be analyzed by an intralaboratory validated SYBR-Green real time PCR analysis (Brusa et al., 2011). The PCR was performed in a $20 \mu \mathrm{l}$ reaction mixture containing $4 \mu \mathrm{l}$ of DNA template, $10 \mu \mathrm{l}$ of PerfeCTa SYBR Green SuperMix, low ROX (Quanta, Biosciences), and $0.2 \mu \mathrm{l}$ of $100 \mu \mathrm{M}$ of each primer. Primer sequences were: stx1-F GCAGATAAATCGCCATTCG, stx1-R TGTTGTACGAAATCCCCTCTG, stx2-F CATGACAAC GGACAGCAGTTA, and stx2-R TGTGGATGCATCTCTGGTCA (Operon, Huntsville, AL, USA). Thermal cycle condition was as follows: 1 cycle at $95^{\circ} \mathrm{C}$ for $10 \mathrm{~min}, 40$ cycles at $95^{\circ} \mathrm{C}$ for $10 \mathrm{~s}$, and $56^{\circ} \mathrm{C}$ for $30 \mathrm{~s}$, followed by a cycle at $95^{\circ} \mathrm{C}$ for $1 \mathrm{~min}, 55^{\circ} \mathrm{C}$ for $30 \mathrm{~s}$, and $95^{\circ} \mathrm{C}$ for 30 s. E. coli O157:H7 EDL933 and E. coli K-12 were used as positive and negative controls, respectively. One milliliter of PCR-positive samples for $s t x_{1}$ and/or $s t x_{2}$ genes were spin down and the pellet was plated onto MacConkey agar (MAC) (Becton Dickinson Co., Sparks, MD, USA) and subsequently, in three consecutive eosin-methylene blue-Levine (Biokard, Zac de Ther, France) agar plates and incubated at $37^{\circ} \mathrm{C}$ for $18 \mathrm{~h}$. The confluent growth zone onto MAC agar was screened for $s t x_{1}$ and $s t x_{2}$ genes by multiplex PCR (Leotta et al., 2005). At least 30 presumptive E. coli colonies were selected from any stx-positive plate for PCR confirmation. STEC strains were isolated in Trypticase soy agar (TSA) (BD Co.), confirmed by multiplex PCR (Leotta et al., 2005), and stored in Trypticase soy broth (TSB) with $30 \%$ and $40 \%$ glycerol at $-20^{\circ} \mathrm{C}$ and $-70^{\circ} \mathrm{C}$, respectively, for further phenotypic and genotypic characterization.

\section{PHENOTYPIC AND GENOTYPIC CHARACTERIZATION OF ISOLATES}

Confirmation of isolates as E. coli was performed through biochemical tests according to Ewing and Edwards (1986). In all STEC $\mathrm{O} 157$ isolates, $s t x_{1}, s t x_{2}$, and $r f b_{\mathrm{O} 157}$ genes were detected by multiplex PCR as described above, while the eae (intimin), ehx (enterohemolysin), and $\mathrm{fli}_{\mathrm{H}}$ ( $\mathrm{H} 7 \mathrm{flag}-$ ellin) genes were investigated as described by Karch et al. (1993), Schmidt et al. (1995), and Gannon et al. (1997), respectively.

Virulence factors for STEC non-O157 isolates were detected as previously described for O157, and also saa (autoagglutinating adhesin) gene was investigated in intimin-negative strains (Toma et al., 2004). The $\mathrm{O}$ and $\mathrm{H}$ antigens were determined by a microagglutination technique in plates and by tube agglutination technique, respectively, with an antisera kit (O1-O186) and $56 \mathrm{H}$ antisera produced by Laboratorio de Referencia de E. coli (LREC) (Lugo, Spain), as described by Blanco et al. (1997). 


\section{RESULTS}

\section{PREVALENCE OF 0157:H7 AND NON-0157 STEC STRAINS}

Among the 90 raw ground beef samples and 360 environmental samples, $25.5 \%$ beef and $4.4 \%$ environmental samples, were positive for STEC O157:H7 while 52.2\% beef and 50.5\% environmental samples were positive for non-O157 STEC strains, by the PCR screening (Table 1). From the 90 meat tables, 90 knives, 90 mincing machines, and 90 manipulator hands analyzed, 2.2, $3.3,6.6$, and 5.5\%, respectively, were positive for STEC O157:H7; while, 55.5, 46.6, 61.1, and $38.8 \%$, respectively, were positive for STEC non-O157 (Table 1). Overall, STEC O157:H7 were isolated from 11/23 (47.8\%) raw ground beef samples and 6/16 (37.5\%) environmental samples $(n=2$ meat table, $n=1$ knife, $n=1$ mincing machine, $n=2$ manipulator hands) (Table 1). STEC non-O157 were isolated from 13/47 (27.6\%) raw ground beef samples and 24/182 (13.2\%) environmental samples $(n=9$ meat table, $n=7$ knife, $n=6$ mincing machine, $n=2$ manipulator hands) (Table 1).

\section{CHARACTERIZATION OF 0157 AND NON-0157 STEC ISOLATES}

Fifty-four STEC isolates ( $n=17$ O157, $n=37$ non-O157) were characterized by phenotypic and genotypic techniques, and then serotyped. STEC O157 characterization proved that all isolates were sorbitol and cellobiose negatives. $\beta$-glucuronidase negative and Biotype $\mathrm{C}$ (rhamnose $+/$ rafinose $+/$ dulcitol + ) was predominant, with only two strains belonging to biotype $\mathrm{D}$ (rhamnose $+/$ rafinose $+/$ dulcitol - ). All STEC O157 isolates harbored eae, ehxA, and fli $\mathrm{C}_{\mathrm{H} 7}$ genes, while $83.4 \%$ were $s t x_{2}$, and $16.6 \%$ were $s t x_{1} / s t x_{2}$-positive. Although all $\mathrm{O} 157$ were $\mathrm{fli}_{\mathrm{H} 7}$-positive, $6 \%$ were non-motile.

All STEC non-O157 strains were sorbitol and orthoNitrophenyl- $\beta$-galactoside (ONPG) positives. Most of the nonO157 strains were $\beta$-glucuronidase positive (73\%), and motile (97.3\%). Among 37 STEC non-O157 isolates, 20 different serotypes were identified, comprising $12 \mathrm{O}$ serogroups (O8, O41, O44, O49, O79, O113, O116, O130, O171, O174, O178, and $\mathrm{O} 181)$ and $8 \mathrm{H}$ antigens, being $\mathrm{H} 19(n=16)$ and $\mathrm{H} 21(n=6)$ the prevalent ones (Table 2). Five strains were O-non-typeable and two strains $\mathrm{H}$-non-typeable. The most prevalent serotypes were O8:H19 and O178:H19 (13.5\%); O174:H28 (10.8\%); O41:H14, O79:H19, O113:H21, O174:H21, and O181:H49 (5.4\%). Other serotypes were isolated just one time (Table 2).

Different stx genotypes occurred among non-O157 strains (Table 2). The frequency of stx genotypes was $s t x_{2}(23 / 37$, $62 \%)$, stx $1 /$ stx $_{2}(13 / 37,35 \%)$, and stx $1(1 / 37,3 \%)$. Distinct virulence profiles were also found. The most frequent ones were $s t x_{1} / s t x_{2} s a a / e h x A$ (11 strains), stx $x_{2}$ (11 strains), and $s t x_{2} / s a a / e h x A$ (10 strains).

It is interesting to notice that in one beef retail market three different serotypes were isolated from the same raw ground beef (O8:H19, O79:H19, and ONT:H19), also the virulence profile among ONT:H19 isolates were different between them. From another retail market multiple strains could be isolated belonging to three different serotypes. One strain O41:H14 serotype isolated from the ground beef, one strain O8:H19 serotype isolated from the manipulator's hands and two strains O178:H19 isolated from meat table and knife. Also, the same serotype could be isolated from different sources in the same retail market. For example O157:H7 was isolated from ground beef, mincing machine, table meat, and manipulator's hands at the same retail market, O113:H2 was isolated from ground beef and mincing machine at another retail market, O174:H28 was isolated from knife and meat table at another retail market, and O181:H49 was isolated from ground beef and meat table at another retail market.

\section{DISCUSSION}

The isolation of STEC from foods is problematic because the bacterium is likely to be present in low numbers, may be sublethally injured and is usually accompanied by large population of competent microflora, including other E. coli. The IMS improved the isolation sensitivity of $\mathrm{O} 157$ strains at least 100-fold (Wright et al., 1994), but the isolation of STEC non-O157 is still a challenge, since non-O157 STEC strains show great genetic and biochemical diversity, and there is no unique phenotypic marker that can differentiate them from other E. coli. At the time the study was conducted, there were no standard methods to detect all the serotypes of STEC non-O157 in meat product, so an enrichment protocol originally used for detecting O157:H7 in meat products by USDA-FSIS was adapted to detect STEC in ground beef and environmental samples (USDA-FSIS, 2010). In order to support the growth of all STEC, novobiocin was not added (Vimont et al., 2007; Kanki et al., 2011) and instead, bile salt No. 3 was added to inhibit gram-positive bacteria (Hussein and Bollinger, 2008). Contamination of STEC in ground beef has been studied by researchers in Botswana, Republic of Ireland, Egypt, the Netherlands, Spain, and Canada samples (Heuvelink et al., 1999; Chapman et al., 2001; Cagney et al., 2004; Magwira et al., 2005; Bohaychuk et al., 2006; Mora et al., 2007; Rhoades et al., 2009) and it has been shown that the prevalence of STEC O157:H7 ranges from 0.4 to $3.7 \%$, while STEC non-O157 ranges from 2.4

Table 1 | Number of STEC PCR-positives samples and strains isolated from different sources.

\begin{tabular}{llllll}
\hline Sample category & $\begin{array}{l}\text { No. of samples } \\
\text { analyzed }\end{array}$ & $\begin{array}{l}\text { No. (\%) of STEC } \mathbf{0 1 5 7} \\
\text { PCR positive samples }\end{array}$ & $\begin{array}{l}\text { No. (\%) of STEC O157 } \\
\text { strains isolated }\end{array}$ & $\begin{array}{l}\text { No. (\%) of STEC } \\
\text { non-O157 PCR } \\
\text { positive samples }\end{array}$ & $\begin{array}{l}\text { No. of STEC non-O157 } \\
\text { strains isolated }\end{array}$ \\
\hline Raw ground beef & 90 & $23(25.5)$ & $11(47.8)$ & $47(52.2)$ & $13(27.6)$ \\
Meat tables & 90 & $2(2.2)$ & $2(100)$ & $50(55.5)$ & $9(18)$ \\
Knives & 90 & $3(3.3)$ & $1(33.3)$ & $42(46.6)$ & $7(16.6)$ \\
Mincing machine & 90 & $6(6.6)$ & $2(16.6)$ & $55(61.1)$ & $6(10.9)$ \\
Manipulator hands & 90 & $5(5.5)$ & $35(38.8)$ & $2(5.7)$
\end{tabular}


Table 2 | Serotypes, source, Shiga toxin genotypes and other virulence markers of the strains studied.

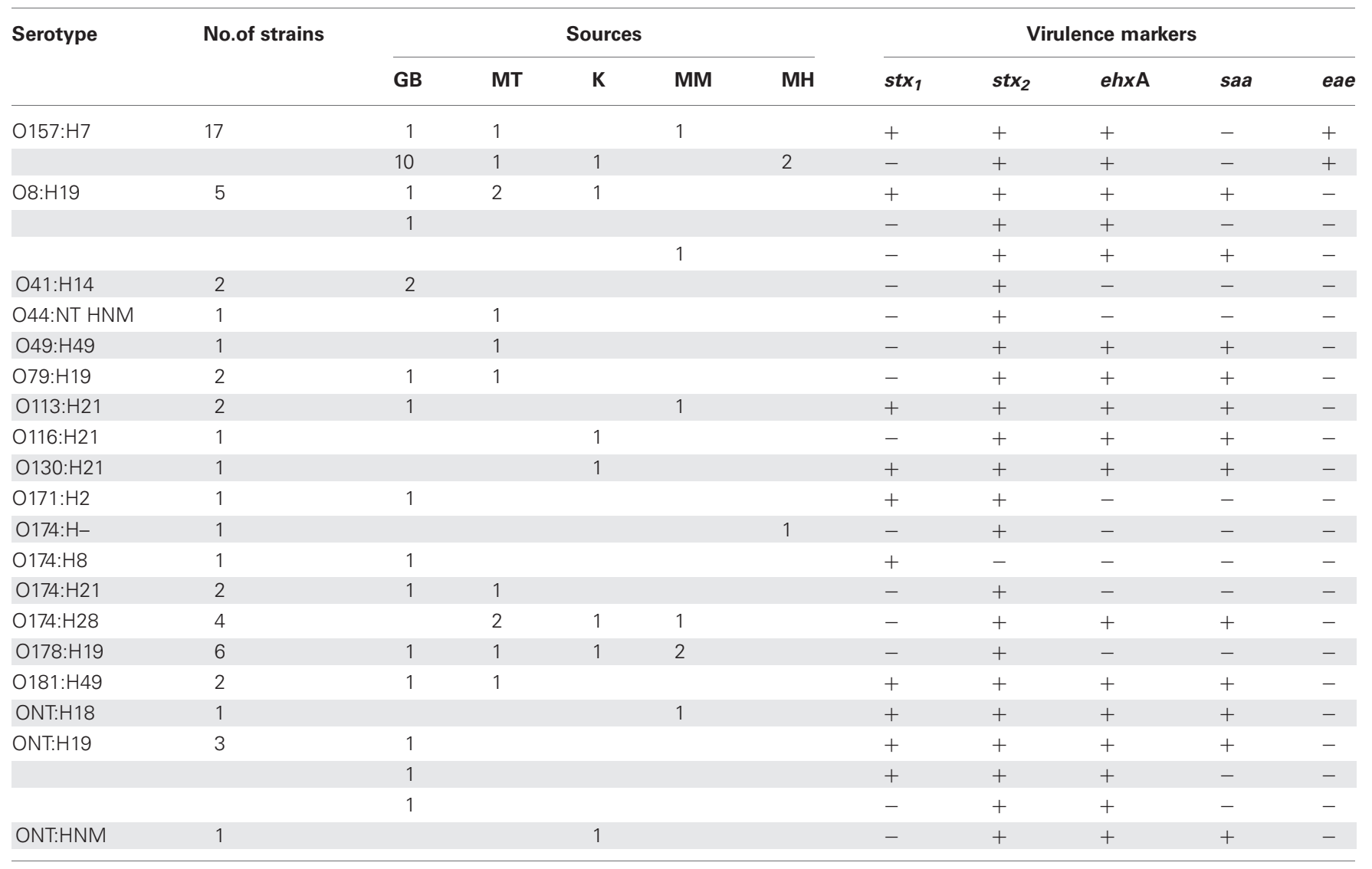

GB, ground beef; MT, meat table; K, knife; MM, mincing machine; MH, manipulator hands; ONT, O-untypeable; HNM, non-motile strains; NT, H-untypeable.

to $30 \%$ (Hussein, 2007). However, studies analyzing meat contact surfaces were not found. In the present study STEC O157 was isolated in $12.2 \%$ of ground beef and $2.2 \%$ of environmental samples, while STEC non-O157 was detected in $14.4 \%$ and $6.6 \%$ of the samples, respectively, although Etcheverría et al. (2010) found $40.74 \%$ in ground beef. Comparing these results with those reported by other countries as the USA showing that $0.3 \%$ of ground beef samples were positive for STEC O157 (Samadpour et al., 2006), or the United Kingdom that reported a $0.8 \%$ prevalence analyzing 6303 samples (Chapman et al., 2001), or Ireland with a $2.8 \%$ of positive samples from 1533 ground beefs analyzed (Cagney et al., 2004), the positive rates for STEC O157 reported in this study are much higher than the previously described above. A recent study in the USA showed that $7.3 \%$ ground beef samples were positive for STEC non-O157 (Bosilevac and Koohmaraie, 2011). In France, 11\% of beef samples were contaminated (Mora et al., 2007), while in Australia the positive rate was 16\% (Barlow et al., 2006), and was similar to the results obtained in the present study. However, it is very difficult to compare different studies as geographical locations, sampling procedures, isolation, and detection methods are different and can affect the prevalence data significantly.

Screening for the presence of $s t x_{1}$ and $s t x_{2}$ by PCR may not have been the best method for the initial determination of prevalence of STEC, since other species of bacteria can possess stx genes. The detection of stx in samples without performing the corresponding strain isolation is incomplete and is regarded as a presumptive diagnosis, but it is valid for the identification of reservoirs (Scheutz et al., 2001). The difference between O157 and non-O157 isolation rates is notably as observed from isolation results obtained in the present study, STEC O157 could be recovered from approximately the $50 \%$ of the beef and $37.5 \%$ of environmental samples analyzed, but STEC non-O157 could only be isolated from $27.6 \%$ of beef samples and $13.2 \%$ of environmental samples. The principal reason is the usage of IMS for O157 strains and the differential phenotypic characteristics that contribute to the identification of these strains. Although Wenting Ju et al. (2012) reported positive rates of $60 \%$ using a colony hybridization procedure targeting stx genes against $27.6 \%$ of isolates obtained in the present work, Bosilevac and Koohmaraie (2011) reported better values using PCR than using colony hybridization. Another difference between non-O157 isolation from ground beef samples and environmental samples lies in the fact that in inert surfaces the bacteria can survive but not multiply, so the number of microorganisms in environmental samples is lower than in the meat, making it harder to be recovered, as it is shown in the present work.

The STEC strains isolated from raw meat did not possess the Locus of Enterocyte Effacement pathogenicity island (LEE PAI) which is most commonly associated with STEC that 
cause outbreaks and severe disease. Karmali et al. (2003) have classified STEC into seropathotypes according to their relative incidence, frequency of involvement in outbreaks and their association with severe disease. According to such a scheme, excluding O8:H19 and O113:H21, all the STEC non-O157 strains in this study are characterized as isolates that cause low human disease incidence, are rarely associated with outbreaks and do not cause severe human disease. Despite the high prevalence of STEC strains in ground beef, occurrence of human disease is low because most of the strains isolated from food lack adherence factors such as eae and $s a a$, which contribute to intestinal colonization and therefore the pathogenicity of the strains. STEC O8:H19 and O113:H21 are important serotypes associated with HUS and HC worldwide, including Argentina (Rivas et al., 2011). They were also recovered from ground beef (Bosilevac and Koohmaraie, 2011) and are one

\section{REFERENCES}

Barkocy-Gallagher, G. A., Arthur, T. M., Rivera-Betancourt, M., Nou, X. W., Shackelford, S. D., Wheeler, T. L., et al. (2003). Seasonal prevalence of shiga toxin-producing Escherichia coli, including O157:H7 and nonO157 serotypes, and Salmonella in commercial beef processing plants. J. Food Prot. 66, 1978-1986.

Barlow, R. S., Gobius, K. S., and Desmarchelier, P. M. (2006). Shiga toxin producing Escherichia coli in ground beef and lamb cuts: results of a one-year study. Int. J. Food Microbiol. 111, 1-5.

Blanco, M., Blanco, J. E., Blanco, J., Mora, A., Rio, M., Prado, C., et al. (1997). Distribution and characterization of faecal verotoxinproducing Escherichia coli (VTEC) isolated from healthy cattle. Vet. Microbiol. 54, 309-319.

Bohaychuk, V. M., Gensler, G. E., King, R. K., Manninen, K. I., Sorensen, O., $\mathrm{Wu}, \mathrm{J}$. T., et al. (2006). Occurrence of pathogens in raw and ready-toeat meat and poultry products collected from the retail marketplace in Edmonton, Alberta, Canada. J. Food Prot. 69, 2176-2182.

Bosilevac, J. M., and Koohmaraie, M. (2011). Prevalence and characterization of non-O157 shiga toxinproducing Escherichia coli isolates from commercial ground beef in the United States. Appl. Environ. Microbiol. 77, 2103-2112.

Brusa, V., Lirón, J. P., Aliverti, F., Aliverti, V., Brocardo, S., and Leotta, G. A. (2011). "Desarrollo y evaluación de dos PCR-RT para la detección de genes stx en carne picada," in First International Congress of Zoonoses and Emerging Diseases and VII Zoonoses Argentine Congress, Abstract book (Buenos Aires: Asociación Argentina de Zoonosis).
Cagney, C., Crowley, H., Duffy, G., Sheridan, J. J., O'Brien, S., Carney, E., et al. (2004). Prevalence and numbers of Escherichia coli O157: $\mathrm{H} 7$ in minced beef and beef burgers from butcher shops and supermarkets in the Republic of Ireland. Int. J. Food Microbiol. 21, 203-212.

Chapman, P. A., Cerdán Malo, A. T., Ellin, M., Ashton, R., and Harkin, M. A. (2001). Escherichia coli $\mathrm{O} 157$ in cattle and sheep at slaughter, on beef and lamb carcasses and in raw beef and lamb products in South Yorkshire, UK. Int. J. Food Microbiol.

Chinen, I., Tanaro, J. D., Miliwebsky, E., Lound, L. H., Chillemi, G., Ledri, S., et al. (2001). Isolation and characterization of Escherichia coli O157:H7 from retail meats in Argentina. J. Food Prot. 64, 1346-1351.

Edwards, J. R., and Fung, D. Y. C. (2006). Prevention and decontamination of Escherichia coli O157:H7 on raw beef carcasses in commercial beef abattoirs. J. Rapid Methods Autom. Microbiol. 14, $1-95$.

Etcheverría, A. I., Padola, N. L., Sanz, M. E., Polifroni, R., Krüger, A., Passucci, J., et al. (2010). Occurrence of Shiga toxinproducing E. coli (STEC) on carcasses and retail beef cuts in the marketing chain of beef in Argentina. Meat. Sci. 86, 418-421.

Ewing, W. H., and Edwards, P. R. (1986). Edwards and Ewing's Identification of Enterobacteriaceae. New York, NY: Elseiver.

Gannon, V. P., D'Souza, S., Graham, T., King, R. K., Rahn, K., and Read, S. (1997). Use of the flagellar H7 gene as a target in multiplex PCR assays and improved specificity in identification of enterohemorrhagic 64, 139-150.

of the most frequent serotypes in Argentine cattle (Masana et al., 2011).

Strains belonging to the same serotype could be isolated from different sources of the same retail market; also, the same serotype could be detected in different stores. However, molecular subtyping of the isolates, such as by pulsed field gel electrophoresis (PFGE), should be done to demonstrate possible clonal relatedness.

\section{ACKNOWLEDGMENTS}

The authors acknowledge the support of Cristian Adriani, from Dirección de Salud de la Municipalidad de Berisso, for his help in the sampling at the retail markets; and to the Municipalidad de Berisso for their support. Victoria Brusa was supported by a fellowship from Universidad Nacional de La Plata (UNLP).

Escherichia coli strains. J. Clin. Microbiol. 35, 656-662.

Guth, B. E. C., Prado, V., and Rivas, M. (2011). "Shiga toxin-producing Escherichia coli," in Pathogenic Escherichia coli in Latin America, ed A. G. T. Torres (Galveston, Texas: Bentham Science Publishers), 65-83.

Heuvelink, A. E., Zwartkruis-Nahuis, J. T., Beumer, R. R., and de Boer, E. (1999). Occurrence and survival of verocytotoxin-producing Escherichia coli $\mathrm{O} 157$ in meats obtained from retail outlets in The Netherlands. J. Food Prot. 62, 1115-1122.

Hussein, H. S. (2007). Prevalence and pathogenicity of Shiga toxinproducing Escherichia coli in beef cattle and their products. J. Anim. Sci. 85, 63-72.

Hussein, H. S., and Bollinger, L. M. (2008). Influence of selective media on successful detection of Shiga toxin-producing Escherichia coli in food, fecal, and environmental samples. Foodborne Path. Dis. 5, 227-244.

Ju, W., Shen, J., Li, Y., Toro, M. A., Zhao, S., Ayers, S., et al. (2012). Non-O157 Shiga toxin-producing Escherichia coli in retail ground beef and pork in the Washington, D.C. area. Food Microbiol. 32, 371-377.

Kanki, M., Seto, K., Harada, T., Yonogi, S., and Kumeda, Y. (2011). Comparison of four enrichment broths for the detection of non-O157 Shiga-toxin-producing Escherichia coli O91, O103, O111, O119, O121, O145 and O165 from pure culture and food samples. Lett. Appl. Microbiol. 53, 167-173.

Karch, H., Bohm, H., Schmidt, H., Gunzer, F., Aleksic, S., and Heesemann, J. (1993). Clonal structure and pathogenicity of Shiga-like toxin-producing, sorbitol-fermenting Escherichia coli O157:H7. J. Clin. Microbiol. 3, 1200-1205.

Karmali, M. A., Gannon, V., and Sargeant, J. M. (2010). Verocytotoxinproducing Escherichia coli (VTEC). Vet. Microbiol. 140, 360-370.

Karmali, M. A., Mascarenhas, M., Shen, S., Ziebell, K., Johnson, S., Reid-Smith, R., et al. (2003). Association of genomic $\mathrm{O}$ island 122 of Escherichia coli EDL 933 with verocytotoxin-producing Escherichia coli seropathotypes that are linked to epidemic and/or serious disease. J. Clin. Microbiol. 41, 4930-4940.

Leotta, G. A., Chinen, I., Epszteyn, S., Miliwebsky, E., Melamed, I. C., Motter, M., et al. (2005). Validación de una técnica de PCR múltiple para la detección de Escherichia coli productor de toxina Shiga. Rev. Argent. Microbiol. 37, $1-10$.

Leotta, G. A., Miliwebsky, E. S., Chinen, I., Espinosa, E. M., Azzopardi, K., Tennant, S. M., et al. (2008). Characterization of Shiga toxinproducing Escherichia coli $\mathrm{O} 157$ strains isolated from humans in Argentina, Australia and New Zealand. BMC Microbiol. 8:46. doi: 10.1186/1471-2180-8-46

Magwira, C. A., Gashe, B. A., and Collison, E. K. (2005). Prevalence and antibiotic resistance profiles of Escherichia coli O157:H7 in beef products from retail outlets in Gaborone, Botswana. J. Food Prot. 68, 403-406.

Masana, M. O., D'Astek, B. A., Palladino, P. M., Galli, L., Del Castillo, L. L., Carbonari, C., et al. (2011). Genotypic characterization of non-O157 Shiga toxin-producing Escherichia Coli in beef abattoirs 
of Argentina. J. Food Prot. 74, 2008-2017.

Masana, M. O., Leotta, G. A., Del Castillo, L. L., D’Astek, B. A., Palladino, P. M., Galli, L., et al. (2010). Prevalence, characterization, and genotypic analysis of Escherichia coli O157:H7/NM from selected beef exporting abattoirs of Argentina. J. Food Prot. 73, 649-656.

Mead, P. S., and Griffin, P. M. (1998). Escherichia coli O157:H7. Lancet 352, 1207-1212.

Mora, A., Blanco, M., Blanco, J. E., Dahbi, G., López, C., Justel, P., et al. (2007). Serotypes, virulence genes and intimin types of Shiga toxin (verocytotoxin)-producing Escherichia coli isolates from minced beef in Lugo (Spain) from 1995 through 2003. BMC Microbiol. 7:13. doi: 10.1186/1471-2180-7-13

Parma, A. E., Sanz, M. E., Blanco, J. E., Blanco, J., Viñas, M. R., Blanco, M., et al. (2000). Virulence genotypes and serotypes of verotoxigenic Escherichia coli isolated from cattle and foods in Argentina. Importance in public health. Eur. J. Epidemiol. 16, 757-762.

Renter, D. G., Morris, J. G., Sargeant, J. M., Hungerford, L. L., Berezowski, J., Ngo, T., et al. (2005). Prevalence, risk factors, O serogroups, and virulence profiles of Shiga toxin-producing bacteria from cattle production environments. J. Food Prot. 68, 1556-1565.

Rhoades, J. R., Duffy, G., and Koutsoumanis, K. (2009). Prevalence and concentration of verocytotoxigenic Escherichia coli, Salmonella enterica and Listeria monocytogenes in the beef production chain: a review. Int. J. Food Microbiol. 26, 357-376.

Rivas, M., Chinen, I., Miliwebsky, E., Galli, L., Repetto, H. A., and Masana, M. (2011) "Epidemiology of Argentinean STEC," in Bacterial Population Genetics: A Tribute to Thomas, S., Whittam, eds S. Walk and P. Feng (Washington, DC: ASM Press), 109-132.

Rivas, M., Padola, N. L., Lucchesi, P. M. A., and Masana, M. (2010) "Diarrheagenic Escherichia coli in Argentina," in Pathogenic Escherichia coli in Latin America, ed. A. G. T. Torres (Galveston, Texas: Bentham Science Publishers), 348-392.

Samadpour, M., Barbour, M. W., Nguyen, T., Cao, T. M., Buck, F., Depaiva, G. A., et al. (2006). Incidence of enterohemorrhagic Escherichia coli, Escherichia coli O157, Salmonella and Listeria monocytogenes in retail fresh ground beef, sprouts and mushrooms. J. Food Prot. 69, 441-443.

Scheutz, F., Beutin, L., and Smith, H. R. (2001). "Clinical detection of verocytotoxin-producing $E$. coli
(VTEC)," in Verocytotoxigenic, E. coli, eds G. Duffy, P. Garvey, and D. A. McDowell (Trumbull, Connecticut: Food and Nutrition Press Inc.), 25-56.

Schmidt, H., Beutin, L., and Karch, H. (1995). Molecular analysis of the plasmid-encoded hemolysin of Escherichia coli O157:H7 strain EDL 933. Infect. Immun. 63, 1055-1061.

Toma, C., Martínez Espinosa, E., Song, T., Miliwebsky, E., Chinen, I., Iyoda, S., et al. (2004). Distribution of putative adhesins in Shiga toxin-producing Escherichia coli of different seropathotypes. J. Clin. Microbiol. 42, 4937-4946.

United State Department of Agriculture, Food Safety, and Inspection Service. (2010). "Detection, isolation and identification of Escherichia coli O157:H7 from meat products. MLG 5.05," in Microbiology Laboratory Guidebook, eds B. P. Dey and C. P. Lattuada (Washington, DC: U.S. Department of Agriculture, Food Safety and Inspection Service), 1-12.

Vimont, A., Delignette-Muller, M. L. and Vernozy-Rozand, C. (2007). Supplementation of enrichment broths by novobiocin for detecting Shiga toxin-producing Escherichia coli from food: a controversial use. Lett. Appl. Microbiol. 44, 326-331.

Wright, D. J., Chapman, P. A., and Siddons, C. A. (1994).
Immunomagnetic separation as a sensitive method for isolating Escherichia coli O157 from food samples. Epidemiol. Infect. 113, 31-39.

Conflict of Interest Statement: The authors declare that the research was conducted in the absence of any commercial or financial relationships that could be construed as a potential conflict of interest.

Received: 01 November 2012; accepted: 29 December 2012; published online: 18 January 2013.

Citation: Brusa V, Aliverti V, Aliverti $F$, Ortega EE, de la Torre JH, Linares LH, Sanz ME, Etcheverría AI, Padola NL, Galli L, Peral García P, Copes $J$ and Leotta GA (2013) Shiga toxinproducing Escherichia coli in beef retail markets from Argentina. Front. Cell. Inf. Microbio. 2:171. doi: 10.3389/fcimb 2012.00171

Copyright (C) 2013 Brusa, Aliverti, Aliverti, Ortega, de la Torre, Linares, Sanz, Etcheverría, Padola, Galli, Peral Garcia, Copes and Leotta. This is an open-access article distributed under the terms of the Creative Commons Attribution License, which permits use, distribution and reproduction in other forums, provided the original authors and source are credited and subject to any copyright notices concerning any thirdparty graphics etc. 